\title{
International Society of Cutaneous Lymphoma (ISCL) and the European Organization of Research and Treatment of Cancer (EORTC) revisions to the staging and classification of mycosis fungoides and Sézary syndrome.
}

\author{
M Duvic, E Olsen
}

\section{Citation}

M Duvic, E Olsen. International Society of Cutaneous Lymphoma (ISCL) and the European Organization of Research and Treatment of Cancer (EORTC) revisions to the staging and classification of mycosis fungoides and Sézary syndrome.. The Internet Journal of Dermatology. 2008 Volume 7 Number 3.

DOI: $\underline{10.5580 / 80 \mathrm{e}}$

\begin{abstract}
Madeleine Duvic, MD, is Professor of Internal Medicine and Dermatology, and Deputy Chairman of the Department of Dermatology at The University of Texas, M. D. Anderson Cancer Center in Houston, Texas. She is a founding member of the United States Cutaneous Lymphoma Consortium (USCLC), a Board member of the International Society for Cutaneous Lymphoma, and also serves as Director of The Cutaneous Lymphoma Clinic at MD Anderson Cancer Center. Dr. Duvic has also served on the Board of Directors of the American Academy of Dermatology (AAD).
\end{abstract}

She is certified in Internal Medicine and Dermatology. She has been a principal and co-principal investigator on numerous clinical trials studying the immunology of T-cell mediated disorders and skin cancers, as well as clinical drug development and translational research in T-cell lymphomas, melanoma, and various skin cancers. A prolific author, she has written manuscripts, book chapters, abstracts, and over 300 peer-reviewed journal articles. She is co-author on a recent book on Retinoids and Carotenoids in Dermatology.

Dr. Olsen is Professor of Dermatology and Oncology at Duke University Medical Center and the founder and Director of the Duke Cutaneous Lymphoma Research and Treatment Center. She is a Past President, SecretaryTreasurer and member of the Board of Directors of the International Society for Cutaneous Lymphomas (ISCL) and has chaired the ISCL initiatives on the revisions to 1) the staging and classification of Mycosis Fungoides (MF) and Sezary Syndrome (SS) (published in Blood 2007) and 2) standardized response criteria and endpoints for MF and SS (in progress). She is a founder and current President of the United States Consortium for Cutaneous Lymphomas (USCCL), a multidisciplinary group whose mission is to enhance patient care through a national registry of patients with cutaneous lymphoma and collaborative clinical trials. She has authored over 90 original articles and is the editor of two textbooks. Dr. Olsen is currently on the Board of Directors of the American Academy of Dermatology (AAD) and Deputy Chair of the AAD Patient Advocacy Task Force.

As background to the following educational activity, this brief review will discuss the International Society of Cutaneous Lymphoma (ISCL) and the European Organization of Research and Treatment of Cancer (EORTC) revisions to the staging and classification of mycosis fungoides and Sézary syndrome.

\section{PURPOSE OF REVISION}

The Mycosis Fungoides Cooperative Group (MFCG) developed a staging system for CTCL ${ }_{1}$ designed for the particular clinical findings in the mycosis fungoides (MF)/ Sézary syndrome (SS) subtypes and based on the TNM (tumor-node-metastasis) classification advocated by the International Union Against Cancer (UICC) ${ }_{2}$ and American Joint Committee on Cancer. ${ }_{3}$ This classification and staging system was modified in conjunction with the National Cancer Institute (NCI) and the Veteran's Administration (VA) Hospital and published in $1979 .{ }_{4}$ 
The updated International Society of Cutaneous Lymphoma (ISCL)/ European Organization of Research and Treatment of Cancer (EORTC) staging and classification applies to MF and SS and has maintained the major components of the MFCG system to allow for continued comparison of patient outcomes within both systems. ${ }_{5}$ WHO/EORTC considers SS to be a separate entity from cases that otherwise meet the criteria for SS but has been preceded by clinically typical MF. 6

\section{PURPOSED CHANGES TO T CLASSIFICATION}

In both the original MFCG $_{4}$ and the revised staging system ${ }_{5}$ , the $\mathrm{T}_{1}$ skin rating is defined as papules, patches, and/or plaques covering less than $10 \%$ body surface area (BSA) and $\mathrm{T}_{2}$ skin rating is defined as patches and/or plaques covering $10 \%$ or more BSA (Table 1 ).

\section{Figure 1}

\begin{tabular}{|c|c|}
\hline \multicolumn{2}{|l|}{ Skin } \\
\hline $\mathrm{T}_{1}$ & $\begin{array}{l}\text { Limited patches," papules, and or plaques }{ }^{\dagger} \text { covering }<10 \% \text { of the skin surface. May } \\
\text { further stratify into } T_{1 a} \text { (patch only) vs } T_{1 b} \text { (plaque } \pm \text { patch). }\end{array}$ \\
\hline $\mathrm{T}_{2}$ & $\begin{array}{l}\text { Patches, papules or plaques covering } \geq 10 \% \text { of the skin surface. May further stratify } \\
\text { into } T_{2 a} \text { (patch only) vs } T_{2 b} \text { (plaque = patch). }\end{array}$ \\
\hline $\mathrm{T}_{3}$ & One or more tumors $(\geq 1$-cm diameter $)$ \\
\hline $\mathrm{T}_{4}$ & Confluence of erythema covering $\geq 80 \%$ body surface area \\
\hline \multicolumn{2}{|l|}{ Node } \\
\hline $\mathbf{N}_{0}$ & No clinically abnormal peripheral lymph nodest; biopsy not required \\
\hline $\mathrm{N}_{1}$ & $\begin{array}{l}\text { Clinically abnormal peripheral lymph nodes; histopathology Dutch grade } 1 \text { or NCI } \\
\text { LN }_{0.2}\end{array}$ \\
\hline $\mathrm{N}_{1}$ & Clone negative" \\
\hline $\mathrm{N}_{\mathrm{lb}}$ & Clone positive* \\
\hline $\mathrm{N}_{2}$ & $\begin{array}{l}\text { Clinically abnormal peripheral lymph nodes; histopathology Dutch grade } 2 \text { or NCI } \\
\mathrm{LN}_{3}\end{array}$ \\
\hline $\mathrm{N}_{2 \mathrm{a}}$ & Clone negative" \\
\hline $\mathrm{N}_{2 \mathrm{~b}}$ & Clone positive* \\
\hline $\mathrm{N}_{3}$ & $\begin{array}{l}\text { Clinically abnormal peripheral lymph nodes; histopathology Dutch grades } 3.4 \text { or } \\
\text { NCI LN }_{4} \text {; clone positive or negative }\end{array}$ \\
\hline $\mathbf{N}_{\mathrm{x}}$ & Clinically abnormal peripheral lymph nodes; no histologic confirmation \\
\hline \multicolumn{2}{|l|}{ Visceral } \\
\hline $\mathrm{M}_{0}$ & No visceral organ involvement \\
\hline $\mathrm{M}_{4}$ & $\begin{array}{l}\text { Visceral involvement (must have pathology confirmation' and organ involved } \\
\text { should be specified) }\end{array}$ \\
\hline \multicolumn{2}{|l|}{ Blood } \\
\hline B0 & $\begin{array}{l}\text { Absence of significant blood involvement: } \leq 5 \% \text { of peripheral blood lymphocytes } \\
\text { are atypical (Sézary) cells! }\end{array}$ \\
\hline $\mathbf{B}_{0 \mathbf{a}}$ & Clone negative" \\
\hline $\mathrm{B}_{06}$ & Clone positive* \\
\hline B1 & $\begin{array}{l}\text { Low blood tumor burden: }>5 \% \text { of peripheral blood lymphocytes are atypical } \\
\text { (Sézary) cells but does not meet the criteria of } B_{2}\end{array}$ \\
\hline $\mathrm{B}_{1 \mathbf{s}}$ & Clone negative" \\
\hline $\mathrm{B}_{1 b}$ & Clone positive* \\
\hline B2 & High blood tumor burden: $\geq 1000 / \mu \mathrm{L}$ Sézary cells! with positive clone \\
\hline
\end{tabular}

\section{TNMB STAGES}

*For skin, patch indicates any size skin lesion without significant elevation or induration. Presence/absence of hypo- or hyperpigmentation, scale, crusting, and/or poikiloderma should be noted.
${ }^{\dagger}$ For skin, plaque indicates any size skin lesion that is elevated or indurated. Presence or absence of scale, crusting, and/or poikiloderma should be noted. Histologic features such as folliculotropism or large-cell transformation (> 25\% large cells), $\mathrm{CD}^{+} 0^{+}$or $\mathrm{CD}^{-} 0^{-}$, and clinical features such as ulceration are important to document.

For skin, tumor indicates at least one 1-cm diameter solid or nodular lesion with evidence of depth and/or vertical growth. Note total number of lesions, total volume of lesions, largest size lesion, and region of body involved. Also note if histologic evidence of large-cell transformation has occurred. Phenotyping for CD30 is encouraged.

${ }^{\S}$ For node, abnormal peripheral lymph node(s) indicates any palpable peripheral node that on physical examination is firm, irregular, clustered, fixed or $1.5 \mathrm{~cm}$ or larger in diameter. Minimal nodal groups examined on physical examination should include cervical, supraclavicular, epitrochlear, axillary, and inguinal. Central nodes, which are not generally amenable to pathologic assessment, are not currently considered in the nodal classification unless used to establish $\mathrm{N}_{3}$ histopathologically.

${ }^{\mathbb{I}}$ For viscera, spleen and liver may be diagnosed by imaging criteria.

"For blood, Sézary cells are defined as lymphocytes with hyperconvoluted cerebriform nuclei. If Sézary cells are not able to be used to determine tumor burden for $\mathrm{B}_{2}$, then one of the following modified ISCL criteria along with a positive clonal rearrangement of the TCR may be used instead: (1) expanded $\mathrm{CD} 4{ }^{+}$or $\mathrm{CD} 3{ }^{+}$cells with $\mathrm{CD} 4 / \mathrm{CD} 8$ ratio of 10 or more, (2) expanded CD $4{ }^{+}$cells with abnormal immunophenotype including loss of CD7 or CD26.

\# A T-cell clone is defined by PCR or Southern blot analysis of the T-cell receptor gene.

In the classification published by the MFCG, $1 \%$ BSA was defined as equal to the "palmar surface of the hand." ${ }_{1}$ but it has since been determined that the palm and fingers of the patient's hand is a better approximation of $1 \%$ BSA. ${ }_{5}$ Another method of determining BSA is to estimate the percentage of skin involvement in each of 12 regions of the body (each with a relative assigned percent $\mathrm{BSA}_{7}$ multiplying this number by the percentage of the BSA for that particular region and adding up the regional percentages to obtain the total BSA involved with MF/SS. 


\section{Figure 2}

Figure 1. Regional percent body surface area (BSA) in the adult

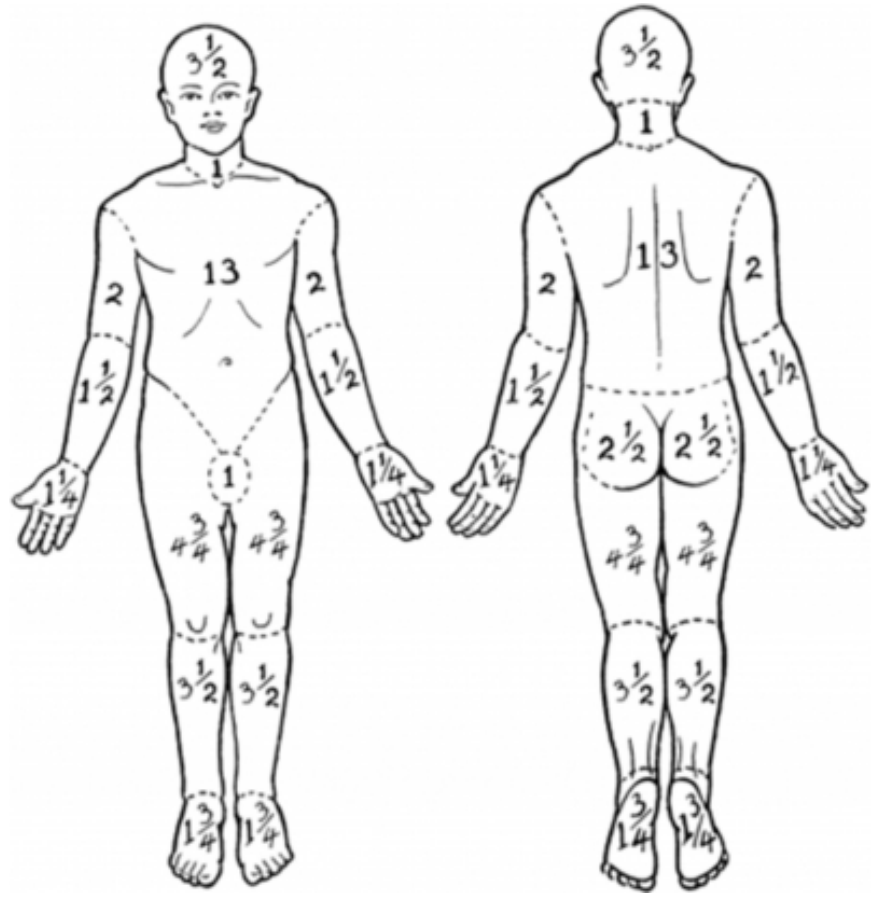

The MFCG originally required that a diagnosis of tumorstage disease include at least 3 tumors, ${ }_{8}$ but this was changed to one or more tumors in the final MFCG staging system. ${ }_{4}$ The proposed ISCL/EORTC classification revision retains the requirement of at least one tumor $(1.5 \mathrm{~cm}$ in diameter) for the definition of $\mathrm{T}_{3} .{ }_{5}$ Whether there should be a minimum histologic depth of infiltrate to distinguish plaque from tumor in order to corroborate this important assignment of $\mathrm{T}$ stage based on a single lesion has not been yet been determined. There is currently no distinction in the updated staging system for subclassifying $\mathrm{T}_{4}$ based on varying degrees of induration, erythema, or scale.

The ISCL/EORTC recommends tracking folliculotropic MF and large-cell transformation to determine if either warrants an advance in stage. Folliculotropic MF has been shown to be associated with a worse prognosis than expected for clinical stage and is considered equivalent to T3 tumors ${ }_{91011}$.

\section{REVISIONS TO THE N (NODE) CLASSIFICATION}

The ISCL/EORTC revision defines clinically abnormal peripheral nodes as $1.5 \mathrm{~cm}$ or larger in the longest transverse diameter or any palpable peripheral node, regardless of size, that on physical examination is firm, irregular, clustered, or fixed. These clinically enlarged or abnormal nodes should be corroborated by an imaging study (computed tomography $[\mathrm{CT}] \pm{ }_{18}$ F-fluorodeoxyglucose positron emission tomography [FDG-PET] or by magnetic resonance imaging (MRI) (in cases where patients may be allergic to contrast dye) or ultrasound prior to biopsy.

Because a biopsy of a clinically abnormal node is not always done at initial staging, the revised ISCL/EORTC classification has added a new category, the Nx node rating, to facilitate capture of at least this clinical information.

\section{PATHOLOGY OF LYMPH NODES}

The two main histopathologic grading systems for lymph nodes in MF/SS are the NCI/VA classification system, 12 first proposed by Matthews and Gazdar, ${ }_{13}$ and the Dutch System $_{14}$ (Table 2). The major difference between these classification systems resides in the criteria used to define "abnormal" lymphocytes. ${ }_{14}$ Specifically, the NCI/VA system, ${ }_{12}$ although it defines abnormal (neoplastic) cells as small $(6-10 \mu \mathrm{m})$ or large $(>11.5 \mu \mathrm{m})$ cells with cerebriform, irregularly folded, hyperconvoluted nuclei (ie, Sézary cells), does not use the size of cells but instead uses the relative numbers of such cells in the paracortex of the lymph node for the $\mathrm{LN}_{0-2}$ definition. The Dutch system uses the diameter of the cerebriform cells ( $>7.5 \mu \mathrm{m})$ to define abnormal (neoplastic) cells, and if present, this constitutes early involvement (grade 2). 14

$\mathrm{N}_{1}$ and $\mathrm{N}_{2}$ ratings can be further classified into 2 subgroups: $\mathrm{N}_{1 \mathrm{a}}$ and $\mathrm{N}_{2 \mathrm{a}}$ (clone negative) and $\mathrm{N}_{1 \mathrm{~b}}$ and $\mathrm{N}_{2 \mathrm{~b}}$ (clone positive). ${ }_{5}$ It is hoped that by capturing this information longitudinally, it can be determined if there is a similar prognosis of patients with and without clonal involvement and between $\mathrm{N}_{2 b}$ and $\mathrm{N}_{3}$.. Prognosis in MF/SS is clearly related to partially or completely effaced nodal architecture as defined by either the NCI-VA $\left(\mathrm{LN}_{4}\right)$ or Dutch (grade 3/4) grading system, ${ }_{15}$ and continues to define the $\mathrm{N}_{3}$ node rating in the updated ISCL/EORTC staging system. 


\section{Figure 3}

\begin{tabular}{|c|c|c|}
\hline $\begin{array}{l}\text { Updated } \\
\text { ISCL/EORTC } \\
\text { classification }\end{array}$ & Dutch system $^{14}$ & NCI-VA classification ${ }^{12,13}$ \\
\hline $\mathrm{N}_{1}$ & $\begin{array}{l}\text { Grade 1: dermatopathic } \\
\text { lymphadenopathy }(\mathrm{DL})\end{array}$ & $\begin{array}{l}\mathrm{LN}_{1} \text { : occasional and isolated } \\
\text { atypical lymphocytes (not arranged } \\
\text { in clusters) } \\
\mathrm{LN}_{2} \text { : many atypical lymphocytes } \\
\text { or in } 3-6 \text { cell clusters }\end{array}$ \\
\hline $\mathrm{N}_{2}$ & $\begin{array}{l}\text { Grade 2: DL; early involvement by MF } \\
\text { (presence of cerebriform nuclei }>7.5 \\
\mu \mathrm{m} \text { ) }\end{array}$ & $\begin{array}{l}\mathrm{LN}_{3} \text { : aggregates of atypical } \\
\text { lymphocytes; nodal architecture } \\
\text { preserved }\end{array}$ \\
\hline $\mathrm{N}_{3}$ & $\begin{array}{l}\text { Grade 3: partial effacement of LN } \\
\text { architecture; many atypical cerebriform } \\
\text { mononuclear cells (CMCs) Grade } 4 \text { : } \\
\text { complete effacement }\end{array}$ & $\begin{array}{l}\mathrm{LN}_{4} \text { : partial/complete effacement } \\
\text { of nodal architecture by atypical } \\
\text { lymphocytes or frankly neoplastic } \\
\text { cells }\end{array}$ \\
\hline
\end{tabular}

\section{REVISION TO M CLASSIFICATION}

To be considered as having visceral disease (stage IVb), documentation of involvement by only one organ outside the skin, nodes, or blood is needed. The ISCL/EORTC considers splenomegaly as visceral disease, even without biopsy confirmation, when it is (a) unequivocally present on physical exam and (b) documented radiographically by either enlargement. ${ }_{5}$,

Liver disease may be suspected by physical examination, abnormal liver function tests, or radiologic tests (CT, FDGPET, liver/spleen scan) but should be confirmed by liver biopsy. 16

The ISCL/EORTC recommends performance of a bone marrow biopsy in patients who have $\mathrm{B}_{2}$ blood involvement or unexplained hematologic abnormalities.

If lung abnormalities or other suggestions of extracutaneous lymphomatous involvement, besides splenomegaly, are found on radiographic examination, pathological assessment is recommended before ascribing this to visceral involvement with MF/SS.

\section{REVISIONS TO THE B (BLOOD) RATING}

The ISCL/EORTC has simplified and clarified the definitions of $B$ to $B_{2}$. B remains $5 \%$ or less Sézary cells. $B_{2}$ is now defined as a clonal rearrangement of the TCR in the blood and either $1.0 \mathrm{~K} / \mu \mathrm{L}$ or more Sézary cells or one of the 2 criteria outlined by the ISCL, ${ }_{17}$ that is, (1) increased CD4 ${ }^{+}$ or $\mathrm{CD} 3{ }^{+}$cells with $\mathrm{CD} 4 / \mathrm{CD} 8$ of 10 or more or (2) increase in $\mathrm{CD} 4{ }^{+}$cells with an abnormal phenotype $\left(\geq 40 \% \mathrm{CD} 4{ }^{+}\right.$ $/ \mathrm{CD} 7^{-}$or $\geq 30 \% \mathrm{CD}^{+} / \mathrm{CD} 26^{-}$has been suggested $\left.{ }^{18}\right)$. $\mathrm{B}_{1}$ is defined as more than $5 \%$ Sézary cells and either less than 1.0 $\mathrm{K} / \mu \mathrm{L}$ absolute Sézary cells, absence of a clonal rearrangement of the TCR, or both.
The assessment of blood tumor burden in MF/SS in the current staging assessment is based on morphologic features of the neoplastic cells alone (eg, Sézary cell counts). ${ }_{19}$ Blood flow cytometry offers an alternate objective means of identifying and quantifying these neoplastic lymphocytes in the blood. The populations of CD4+CD26- or CD4+CD7cells or $\mathrm{V}$ beta subtype measured by flow can be used to identify the population of SS cells.

\section{EVALUATION AND STAGING OF THE PATIENT WITH MF/SS}

The staging of MF/SS according to the TNMB system implies that an appropriate evaluation of the 4 TNMB systems has been performed. The recommended workup is detailed in Table 3 below.

\section{Figure 4}

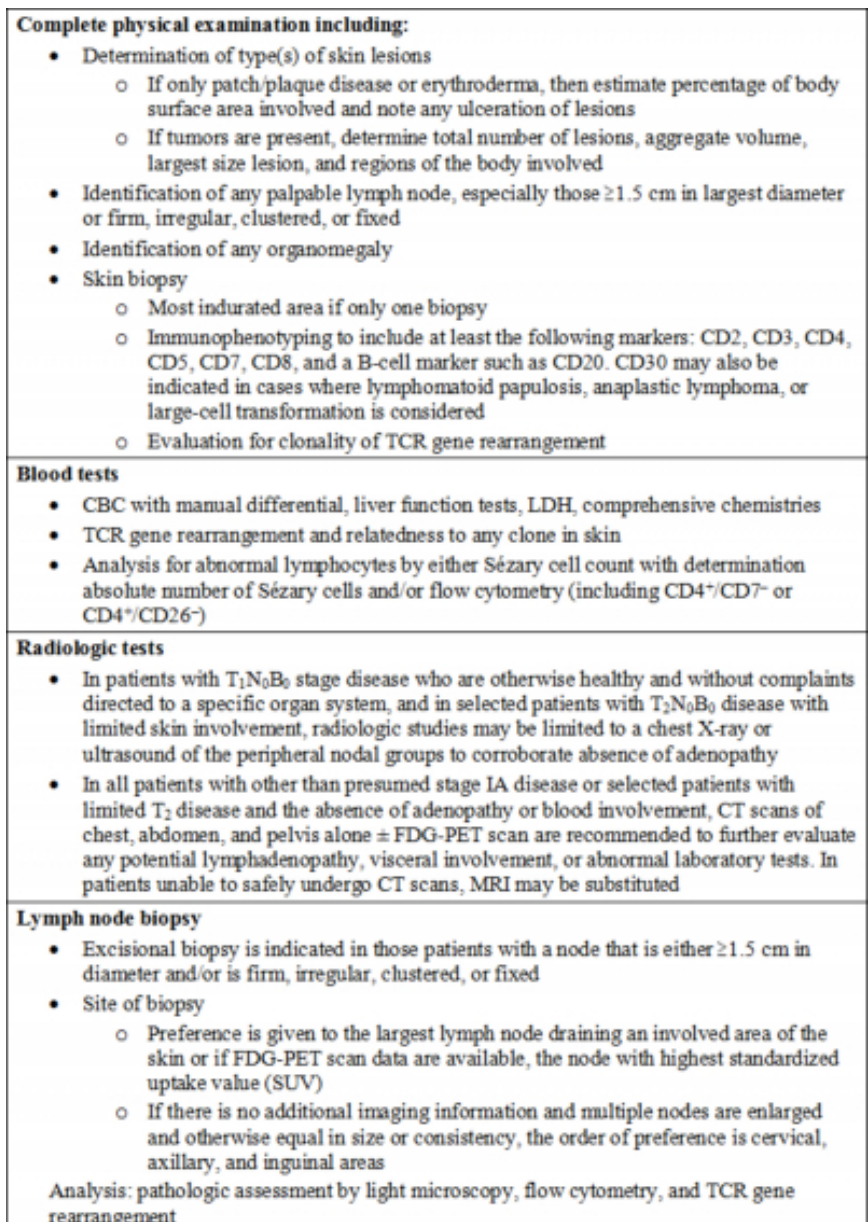

\section{CONCLUSIONS}

Although the ISCL/EORTC revisions to the staging and classification of MF and SS further narrows and defines the variables involved, it does not provide a finite staging 
system that inherently incorporates all potential prognostic factors.

\section{References}

1. Lamberg SI, Diamond EL, Lorincz AL, et al. Mycosis fungoides cooperative study. Arch Dermatol 1975;

111:457-459

2. Harmer MH. TNM Classification of Malignant Tumours. 1978; 3rd ed. Geneva, Switzerland UICC-International

Union Against Cancer.

3. Oliver HB, Carr DT, Rubin P, et al. American Joint

Committee on Cancer: AJCC Cancer Staging Manual. 1978;

1st ed. Chicago, IL Whiting Press.

4. Bunn PA and Lamberg SI. Report of the committee on staging and classification of cutaneous T-cell lymphomas. Cancer Treat Rep 1979; 63:725-728.

5. Olsen E, Vonderheid E, Pimpinelli N, Willemze R, Kim

$\mathrm{Y}$, Knobler R et al. Revisions to the staging and

classification of mycosis fungoides and Sézary syndrome: a proposal of the International Society for Cutaneous Lymphomas (ISCL) and the Cutaneous Lymphoma Task Force of the European Organization of Research and Treatment of Cancer (EORTC). Blood.

2007;110:1713-1722.

6. Willemze R, Jaffe ES, Burg G, et al. WHO-EORTC classification for cutaneous lymphomas. Blood 2005; 105:3768-3785

7. Lund CC and Browder NC. The estimation of areas of burns. Surg Gynecol Obstet 1944; 79:352-358

8. Lamberg SI, Green SB, Byar DP, et al. Clinical staging for cutaneous T-cell lymphoma. Ann Int Med 1984; 100:187-192

9. Bonta MD, Tannous ZS, Demierre M-F, Gonzalez E, Harris NL, Duncan LM. Rapidly progressing mycosis fungoides presenting as follicular mucinosis. J Am Acad Dermatol 2000; 43:635-640

10. Gilliam AC, Lessin SR, Wilson DM, Salhany KE.
Folliculotropic mycosis fungoides with large cell transformation presenting as dissecting cellulitis of the scalp. J Cutan Pathol 1997; 24:169-175.

11. van Doorn R, Scheffer E, Willemze R. Follicular mycosis fungoides, a distinct disease entity with or without associated follicular mucinosis. Arch Dermatol 2002; 138:191-198

12. Sausville EA, Worsham GF, Matthews MJ, et al. Histologic assessment of lymph nodes in mycosis fungoides/Sézary syndrome (cutaneous T-cell lymphoma): clinical correlations and prognostic import of a new classification system. Human Pathol 1985; 16:1098-1109 13. Clendenning WE and Rappaport HW. Report of the committee on pathology of cutaneous $\mathrm{T}$ cell lymphomas. Cancer Treat Report 1979; 63:719-724

14. Scheffer E, Meijer CJLM, van Vloten WA.

Dermatopathic lymphadenopathy and lymph node involvement in mycosis fungoides. Cancer 1980; 45:137-148.

15. Vonderheid EC, Diamond LW, van Vloten WA, et al. Lymph node classification systems in cutaneous T-cell lymphoma: evidence for the utility of the working formulation of non-Hodgkin's lymphomas for clinical usage. Cancer 1994; 73:207-218

16. Huberman MS, Bunn PA, Matthews MJ, et al. Hepatic involvement in the cutaneous T-cell lymphomas: results of percutaneous biopsy and peritoneoscopy. Cancer 1980; 45:1683-1688

17. Vonderheid EC, Bernengo MG, Burg G, et al. Update on erythrodermic cutaneous T-cell lymphoma: report of the International Society for Cutaneous Lymphomas. J Am Acad Dermatol 2002; 46:95-106

18. Vonderheid EC and Bernengo MG. The Sézary syndrome: hematologic criteria. Hematol Oncol Clin N Amer 2003; 17:1367-1389.

19. Vonderheid EC, Pena J, Nowell P. Sézary cell counts in erythrodermic cutaneous T cell lymphoma: implications for prognosis and staging. Leuk Lymphoma 2006; 47:1841-1856 
International Society of Cutaneous Lymphoma (ISCL) and the European Organization of Research and Treatment of Cancer (EORTC) revisions to the staging and classification of mycosis fungoides and Sézary syndrome.

\section{Author Information}

Madeleine Duvic, M.D.

Division of Internal Medicine, Department of Dermatology, The University of Texas, M.D. Anderson Cancer Center

Elise Olsen, M.D.

Department of Dermatology and Oncology, Department of Dermatology, Duke University Medical Center 